\title{
The Roman plays: an actor's view
}

\section{Oliver Ford Davies}

\section{(2) OpenEdition \\ Journals}

Electronic version

URL: http://journals.openedition.org/shakespeare/502

DOI: 10.4000/shakespeare.502

ISSN: 2271-6424

\section{Publisher}

Société Française Shakespeare

\section{Printed version}

Date of publication: 1 November 1984

Number of pages: 157-168

Electronic reference

Oliver Ford Davies, "The Roman plays: an actor's view », Actes des congrès de la Société française Shakespeare [Online], 5 | 1984, Online since 01 January 2007, connection on 01 May 2019. URL : http:// journals.openedition.org/shakespeare/502 ; DOI : 10.4000/shakespeare.502 
SOCIETE FRANÇAISE SHAKESPEARE

Actes du Congrès 1983

\section{MYTHE ET HISTOIRE}

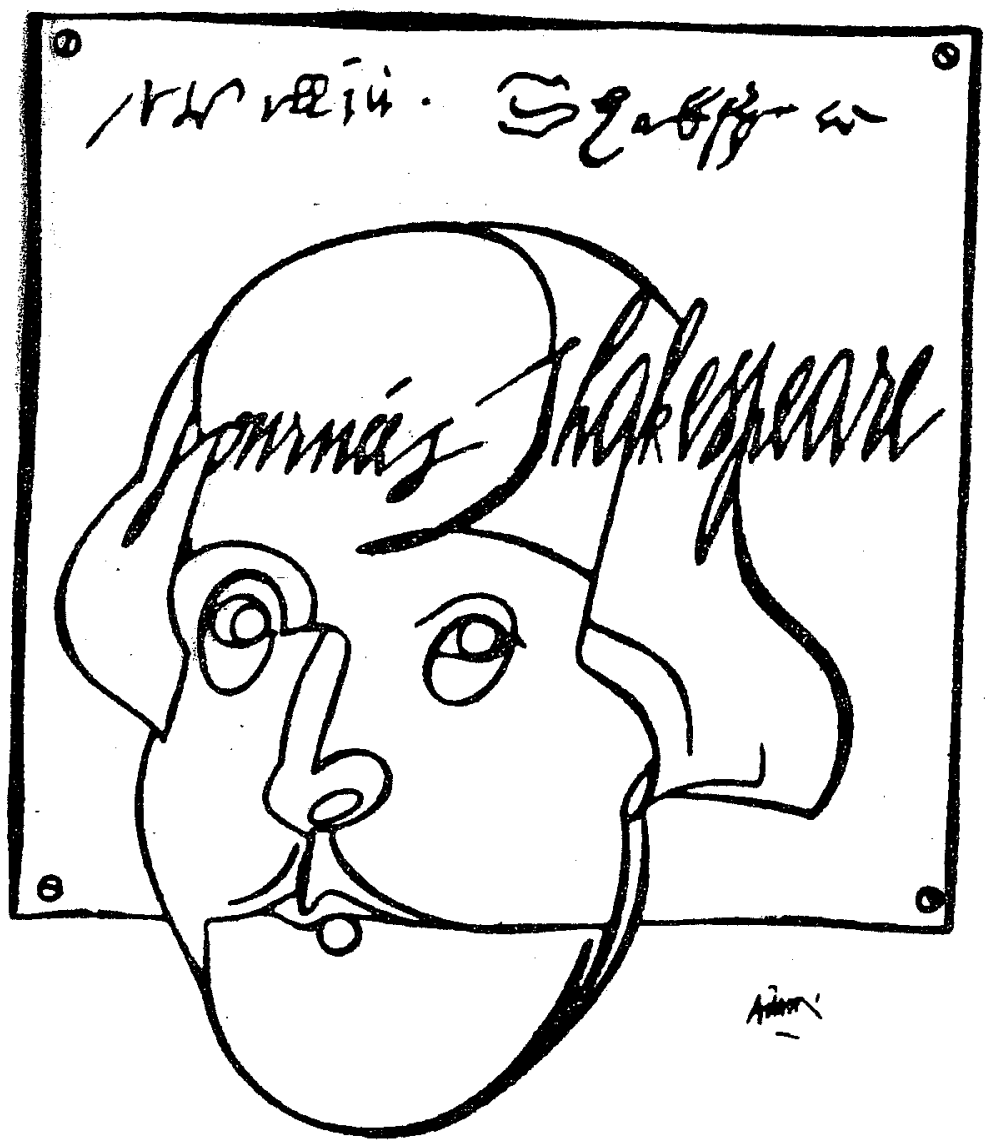

$$
\begin{array}{r}
\text { DiReCteur DE LA' PUblicatic } \\
\text { M.T. Jones-Davie }
\end{array}
$$

Publié avec le concours du Centre National de la Recherche Scientifiq

$$
\text { JEAN TOUZOT Libraire - Editeur }
$$

38, rue Saint-Sulpice 75278 PARIS CEDEX 06199 


\section{THE ROMAN PLAYS : AN ACTOR'S VIEW}

Like most English schoolboys I was brought up with the usual myths about the French : that they did not appreciate Shakespeare, could not understand with their logical minds how anyone could mix tragedy and comedy, and could not take Othello seriously as it all turned on a mouchoir. I was led to believe that French audiences only went to the theatre to hear Racine or a lengthy tirade delivered in a manner Bernhardt would have found dated. Four visits to France with Shakespeare productions have, happily, routed such prejudices.

In 1960 I visited French universities in an Oxford University production of Measure for Measure by Dr. Merlin Thomas. At Aix-en-Provence we attended a lecture on the play in which the speaker detected three levels of chastity in Isabella, to the great intimidation of the actress. We had learnt that the French take their Shakespeare very seriously indeed. In 1963 we came with Othello and found that mouchoirs were quite acceptable in tragedy, though we were puzzled by a Lyons review that described me as «féroce comme Orson Welles», only to be told that the play was then most familiar to French audiences through Welles' film and Verdi's opera.My last two visits have been with the R.S.C. (Royal Shakespeare Company). In 1976 we came with Terry Hands' production of Henry $V$, and in 1979 with his production of Coriolanus . Both plays drew packed houses at the Odéon Theatre and enormous public interest. We approached the performances of Coriolanus with some trepidation, as we heard that De Gaulle had banned the play for a time in 1958, and that in 1934 it had been drawn into the Fascist rioting that helped to bring down the Daladier government. Despite the large demonstrations against dismissals in the steel industry then in progress, our performances were uninterrupted, aided perhaps by Hands' overriding commitment to playing 
the text «straight». This attempt by the director not to take sides did not of course prevent him from being attacked by sections of the French press as too right wing and by sections of the German press as too left wing!

These two recent tours demonstrated to me a great hunger in Western Europe for Shakespeare played «straight» - the term so often used by press and audiences alike. Terry Hands' determination to let the text speak for itself released great complexities and contradictions in both plays. Audiences were fascinated that Henry $V$ both glorified war and questioned its justification, and that Coriolanus was no fascist monster nor the tribunes Marxist extremists. Naturally when the R. S. C. tours with Shakespeare it recognizes the automatic reverence that would be given to, say, the Comédie Française in Molière or the Vienna Philharmonic in Beethoven, but the enthusiasm of audiences all over Western Europe far surpassed such a dutiful response. It is a great sadness to us that our government will not fund the British Council sufficiently to allow us to tour more regularly.

My title is an actor's view of the Roman plays, and I shall try to tie it in with your previous discussions on myth and history. I shall talk mainly about Julius Caesar and Coriolanus, with reference to the English history plays. Perhaps because I was myself a university teacher of history, I am particularly interested in what an actor can bring to academic discussions of text and background. I am convinced that it is still a largely unexplored field, partly through the difficulty of describing the acting process and partly through the actor's reticence about, in Ralph Richardson's words, «spilling the beans». This paper is no place to attempt a thorough analysis, but I hope I may make some pointers to further discussion.

In the Roman and history plays the actor is often confronted with playing a figure of myth - Coriolanus, Julius Caesar, Brutus, Antony, Cleopatra, Henry V, Richard III, Henry VIII. In addition there are a host of subsidiary figures which have attained legendary proportions at least to English audiences - John of Gaunt, Falstaff, Joan la 
Pucelle, Warwick the Kingmaker, Queen Margaret, Katherine of Aragon. The history plays carry the problem of how far one should accept the Tudor myth of the fifteenth century, which so dominated Shakespeare, or how far try to correct his often ludicrous bias. Henry VIII played without some regard for the bureaucratic revolution in government would fail to enrich a strand in the play which Shakespeare (and Fletcher ? ) are certainly aware of. Richard III played as a sober administrator would on the other hand hardly serve the text. The Roman plays have the further problem of where to set the action historically. In Julius Caesar is Shakespeare writing about 44 B. C. or conspiracy torn Guy Fawkes England ? Should one set Coriolanus in a semi-mythical fifth century Rome, amid the corn riots of Jacobean England, or in some modern state hovering on the verge of fascism ? It is tempting to dismiss this as a director's problem, but in all the debate about «director's theatre» it is overlooked that the actor is grappling with the same problems, often line by line. For example when Brutus says in the forum that Antony shall have "a place in the commonwealth, as which of you shall not», what exactly is he offering? The respublica did not mean the same as the Jacobean «commonwealth». What place in the Roman republic could an unemployed plebeian expect from Brutus' promised regime ? When the leaders of the English parliamentarians in the 1640s spoke of the «commonwealth», what rights did they envisage for yeomen, labourers and servants ? An understanding of this problem is essential to all the actors in the scene. Menenius' description of the tribunes in Act II, Scene i makes them out to be Jacobean J. Ps. What kind of court is it then that the tribunes set up in Act III, Scene iii - Roman or Elizabe than?

It is possible to brush aside such problems with the formula, «everything lies in the text». The text is the starting point of the actor's search, and certainly when it comes to performance the all-important end, but it is by no means the complete middle. The actor has many tools at his disposal, and by this I mean not only Stanislavski and 
Freud but also a sense of both the present and the past. Few things are more difficult to describe than the rehearsal process. On the surface there is a degree of consistency and order; discussions of the text and of characters' intentions and relationships; then experiment, blocking, further experiment, and growth towards a highly detailed end product. But not far below the surface lies a jumble of different enquiries, impressions and influences, some barely related to the text, as the actor stumbles towards finding a centre to his character, towards erecting a structure from which he can «swing freely». Even at a late stage of rehearsal an actor is capable of speaking the text with apparent understanding and reproducing a complex series of moves, without feeling that he yet «knows who he is». Then, hopefully, comes a point when the actor makes the necessary break-through, feels himself centred, makes the text his own. This is for me the most exciting moment in the preparation of a production; when suddenly the actor earns the right to speak those words, when it is recognized that the person who did and said what is laid down for Hamlet might justifiably be the character the actor has created. In order to communicate this discovery the actor in Shakespeare relies principally upon the text, the essential bridge to the audience. The R.S.C is in continual debate over language and verse speaking, the means by which the form and structure of the verse can be observed without losing either the actor or the character's individuality. What is not in question, however impassioned the disagreements over means, is that the end lies in the language. One thing our tours abroad have taught me is that language communicates itself at a level far deeper and more complex than the understanding of the precise meaning of words.

Peter Brook has said that a good production of Shakespeare reveals one seventh of the play, and an exceptional production two sevenths. There is no complete production of a Shakespeare play. It is natural to hanker after one, to think there must be some objective test whereby a Coriolanus set in Jacobean England can be better or worse than one set in the French Revolution or 1930s Germany. 
But I suspect a Julius Caesar played in togas on a formal classical set, spanning both authenticity and timelessness, can have equal validity with a production set in modern South America, where dictatorship and manipulation of the mob may seem more immediate and more universal. Each may reveal a different one, or even two, sevenths of the play. Each may, in turn, reveal more to one decade than another. A production valid in expansionist 1968 may seem invalid in deflationary 1983.

Let me describe one rehearsal process where particular outside forces played an important part in shaping a production. In 1975 Alan Howard returned to the company after four years to play Henry $\mathrm{V}$ under Terry Hands' direction. In that period he had toured the world for over a year as Theseus/ Oberon in Peter Brook's A Midsummer Night's Dream and become something of an international star. By the end of 1974 the R.S.C were in an extremely precarious financial position and the continuance of its London base was threatened. The 1975 Stratford season involved fewer plays and fewer actors but had to attract larger audiences. The parallels between life and art seemed clear. Both Alan Howard and Henry $V$ were stars, but as yet largely unknown quantities to their supporting companies, whom it was crucial they led to success. How would Alan/Henry respond to this responsibility thrust upon him, and, as important, how would the company respond to him ? We improvised for some time on this theme, feeling our way through the various tests that Henry has to endure before he achieved victory late in the play. This was the starting point of playing: Act $I$ in rehearsal clothes. Costume and crown were a right to be earned, not taken for granted. Agincourt was not of central importance to Shakespeare. What interested him was how the company was forged, how Henry achieved leadership and trust in so short a time, how he faced the justification of war and bloodshed, and finally how he found himself part of a true «band of brothers» - a temporary band, like a theatre company, forged for one occasion and then dishanded, the former hierarchy undisturbed. Such parallels fed our understanding of the text in a way linguis- 
tic analysis alone could not have achieved.

A knowledge of history also came to our aid. I played the first character to enter in costume, the French ambassador bearing the mythical tennis balls. We discovered that the real ambassador had been the archbishop of Bourges, a fact presumably unknown to Shakespeare. The knowledge that he was a cleric and a seasoned diplomat, rather than a tennis playing young aristocrat, radically affected both my characterization and my costume. Such research can do a great deal to enhance the actor's preparation. Brutus and Cassius had both served Pompey at the Battle of Pharsalus and had subsequently been pardoned by Caesar. The knowledge of whose side the conspirators had fought on in the Civil War does much to enrich Act II, Scene ii, when Caesar greets them before proceeding to the Senate. In ii Henry VI the contemporary rumour that Queen Margaret's child was by Somerset rather than Henry created an interesting triangle between the three characters concerned, which the text will admit if not directly warrant. The point is that we felt Shakespeare would have approved this. He revelled in Plutarch and Holinshed's detail. In the opening of Plutarch's «Life of Coriolanus» he remarks on Marcius' ancestors, «Publius and Quintus who brought to Rome their best water they had by conducts». Hence when the tribune Junius Brutus comments in Act II, Scene iii on the stock which Coriolanus springs from he remarks :

Of the same house Publius and Quintus were, That our best water brought by conduits hither.

At first sight this appeared an obscure couplet, ripe for cutting. But the provision of water was of central importance to the Roman plebeians, and we found that this touch of social realism gave an extra dimension to the interchange. In Julius Caesar we were puzzled by the inclusion in Act V, Scene iii of Titinius' suicide, and concluded that Shakespeare so loved Plutarch's ironic detail of the crowning of dead Cassius with the victory garland that he rather clumsily introduced Titinius into the action to give 
greater substance to Cassius' death. Historical evidence is to be handled with care in relation to the plays. To attempt to make historical sense of the last scene of Henry VIII would be a futile exercise ! Nevertheless the actor playing Othello, the Duke in Measure for Measure, or Don John in Much Ado about Nothing would give much for the historical background he could bring to Richard II, Brutus or Wolsey.

I would like to consider now in a little more detail the actor's approach to Brutus and Coriolanus. Any actor playing Brutus is naturally conditioned by Antony's description at the end of the play:

This was the noblest Roman of them all.

All the conspirators save only he

Did that they did in envy of great Caesar;

He only, in a general honest thought

And common good to all, made one of them.

It is a weighty, seemingly definitive summation. Is this what Shakespeare intends us to think ? I have learned to be wary of what one character says about another in Shakespeare. Characters usually tell the truth, unless we are told they are lying. That is to say they tell the truth as they see it, but not necessarily the way anyone else in the play, or indeed the author, perceives it. Take the tribunes in Coriolanus. Menenius, after calling them «unmeriting, proud, violent, testy, foolish, ridiculous», continues:

You are ambitious for poor knaves' caps and legs : you wear out a good wholesome forenoon in hearing a cause between an orange-wife and a faucet-seller, and then rejourn the controversy of threepence to a second day of audience. When you are hearing a matter between party and party, if you chance to he pinched with the colic, you make faces like mummers, set up the bloody flag against all patience, and, in roaring for a 
chamber-pot, dismiss the controversy bleeding, the more entangled by your hearing. All the peace you make in their cause is calling both the parties knaves. You are a pair of strange ones.

The picture Menenius paints is of two Warwickshire J. P.s setting up court in Chipping Camden market house and proving totally self-centred and ineffective. It practically gives the actor his character, his movement, his make-up. It is a brilliant description, but is it true ? Is the tribune's reply that Menenius is a «perfecter giber for the table than a necessary bencher in the Capitol» any more true ? I suggest that neither turn out to be accurate. Menenius underestimates the resource of the tribunes, as many a patrician politician has disregarded trade union leaders, and vice versa. It is a dangerous «stage direction». Freed from that preconception, the actors playing the tribunes may turn to the rest of the text, which suggests they are neither bumblers nor machiavels but by turn fashion events and are fashioned by them.

Brutus tells us several times that he is noble, that «he bears too great a mind», that he is "armed so strong in honesty.» $\mathrm{He}$ is acutely aware of his destiny as the descendant of the scourge of the Tarquins. As a Brutus he is something of a legend in his own lifetime, as the deference shown by the other conspirators makes clear, but when called upon to justify his intentions at the beginning of Act II, Scene $\mathrm{i}$ (the orchard scene) he is hard put to find a reason that most people would accept as an endorsement of political assassination. Three times he stresses that Caesar has not yet shown tyrannical signs, and his only solid motive is that Caesar mal prove tyrannical; «then, lest he may, prevent», and «therefore think him as a serpent's egg/Which, hatched, would, as his kind, grow mischievous, / And kill him in the shell». The actor must decide whether this is a weak but honest argument, or whether Brutus is dishonest in not facing the possibility that Caesar might not grow mischievous. Brutus is in no doubt that he must lead. Time and again he browbeats others, particularly Cassius. In the or- 
chard he has his way against majority opinion on the oath taking, the inclusion of Cicero, and the killing of Antony. A string of decisions - the sparing of Antony, allowing him to speak in the forum, the return to Philippi to give battle ... prove disastrous. Shakespeare was not out, however, to debunk Brutus. He was no Lytton Strachey, toppling the great Victorians from their pedestals. Brutus is shown on many occasions to think more of the common good than his own self aggrandizement. Caesar is shown to have far greater arrogance, particularly in his relation to the Senate. Shakespeare draws a complex Brutus because he was incapable of writing ten lines without presenting contrast and paradox, and of this the actor must be acutely aware. If as an actor I find the part of Brutus unsatisfactory it is not so much through a failure in characterization as a lack of focus in the play. A greater concentration either on one individual or on the group of conspirators would make the issues more accessible.

Shakespeare certainly remedied this lack of focus when he came to write his last great tragedy, Coriolanus. The play is nearly a thousand lines longer than Julius Caesar. but there is an extraordinary concentration on the central figure. I like to think of Shakespeare handing the script to Burbage, who probably played the part, with the comment: «here is your ultimate test - a basically unsympathetic tragic hero, who changes comparatively little; silent by nature, but who never stops talking or being talked of $\gg$. To achieve variety in the part is a supreme test of the actor. Shakespeare had greater freedom with Coriolanus because, although Plutarch's «Life» gave him a reasonable framework, our knowledge of fifth century Rome is not extensive. Coriolanus was nearly as much a legend to Plutarch as to the Renaissance. For this reason «versions» of "Coriolanus» in this century have been legion. When we toured Germany in 1979 we played at the Thalia Theatre in Hamburg only two years after Hans Hollmann's version, which removed all sympathetic traits from Coriolanus, cut Tullus Aufidius, and set out to show the danger of "Spezialismus», of being a specialist in war in particular, and how 
this allowed the rise of the power of the tribunes. It is true that Coriolanus is a war specialist, though not I think simply «a killing machine». Terry Hands stressed that the universality of the play lay in society's need for an individual of remarkable gifts in time of crisis and the subsequent failure to find a place for him in the community when the crisis was past. I have never been in a production where more emphasis was laid on communicating the text. We were forbidden to «characterize». «Make the options clear» was the director's constant plea. As we struggled towards this goal, it became evident that everyone in the play wanted Coriolanus in his or her own image. He had to embody everyone in the play, and in that way he came to embody Rome. There lay the root of the myth. As Professor Brockbank has argued, Rome had failed to reconcile the rival martial and political virtues that sustained its early growth and needed Coriolanus' death to achieve a balance, leaving the community chastened but renewed ( $\mathrm{Co}$ riolanus : Arden ed., pp. 42, 66). At the end of the play we felt that everyone was diminished by his death.

But as Coriolanus plays out his failure to adapt to society, Shakespeare is determined to show that the stages by which this happens are fluid and haphazard. There is no machiavellian plot by the tribunes, no unconquerable will of the people, no relentless drive towards self destruction by Coriolanus. The possibility of some accommodation is continually present, only to be destroyed by a final lack of understanding on both sides. When Junius Brutus speaks of Coriolanus as «a worthy officer in the war, but insolent, overcome with pride», his words seem justified. But when he calls him «ambitious past all thinking», one feels that Coriolanus was never ambitious for power in the terms Brutus can comprehend. It is Shakespeare's most political play, and in it I find Shakespeare amplifies the dichotomy of inevitability and chance in the unfolding of events.

This dichotomy is a creative tension of which the actor is acutely aware. When preparing a part one is aware of observing an architecture, of creating a structure. When acting the part one can only play one moment at a time. 
The enemy of truthful acting is anticipation. As soon as the actor begins to play the structure, or the scene, or even the paragraph, he is lost. Naturally there are headings. Most long speeches in Shakespeare carry a headline that announces the question, or the theme, much as the sonnets do. But the argument must be allowed to develop from idea to idea, from image to image, never channelled into some undeviating torrent. The musical analogy is appropriate. «Play one note at a time»: Shakespeare wrote like Mozart, not Wagner. In the structure of his plays there are always inconsistencies. One idea, one scene is laid alongside another in contrast. Antithesis and apposition are often the keys to the verse, and must be observed. There is no more painful sight in rehearsal than to watch an actor ironing out the inconsistencies that his author has carefully written in for him. Paradox should not be the enemy of myth, undermining its sure foundations, but its liberator.

Oliver FORD DAVIES 